\title{
Urban Public School Principals' Perception about Physical Education (PE) and Self-Evaluation on Their PE Programs - from New York City, USA 美國紐約公立學校校長對體育及體育課程的評價
}

\author{
Howard Z. Zeng \\ Brooklyn College of the City University of New York, U.S.A.
}

曾振豪

美國紐約城市大學布魯克林學院

\begin{abstract}
Physical activities in school PE programs have been recognized as ideal paths and environments for developing a healthy lifestyle. Researchers have indicated that principals at all school levels (K-12) would be the critical players in the reform efforts for physical activities and improve their PE programs. This study examined 46 principals' PE perception. The Principal's perception of Physical Education Questionnaire and the Self-Evaluation Tool for School Physical Education Program were employed for this survey. Finding included (a) the top three statements that strongly structured the principals' PE perception were Item 2 (We can activate and foster the physical activity skills children need through our school physical education programs), 11 (Once physical education and daily physical activities are valued and supported, children will gradually form their active and healthy lifestyle., and item 1 (Physical education plays a vital role in our school curricula). Regarding self-evaluation for their school PE Program, the principals indicated that their school PE programs were not wellestablished; some particular areas were far from satisfaction. The relationship between the principals' PE perception and selfevaluations on their schools' PE program exists with some correlations stronger than others.
\end{abstract}

Key words: lifestyle, curriculum, reform.

\section{摘 要}

身體活動是學校體育課程中已被確認為發展健康的生活方式的理想途徑和環境。研究表示, 提高學校體育課程的品質中, 各 級學校的校長 (從小學到高中) 將是關鍵的人物。本研究搜集了 46 名校長的體育看法。調查問卷是 : 校長對體育的看法調查問卷 和學校體育教育計畫的自我評估量表。本調查發現: 校長對體育認知 的前三項構成最強烈的影響: 分別為: 我們可以啟動並促 進兒童需要的身體活動技能通過我們的學校體育教育計畫; 身體教育和日常身體活動得到重視和支持, 孩子們就會逐步形成自己 的積極和健康的生活方式; 在我們的學校課程中, 體育教育起著至關重要的作用。關於他們對自己學校的體育課程的自我評價, 校長們表示, 他們的學校體育教育計畫尚未很好地建立起來, 在一些特定的領域仍未得到校長們的滿意。

關鍵字：生活方式，課程設置，改革

\section{Introduction and Background}

For over two decades, researchers have realized and emphasized that physical education (PE) plays a vital role in our school education (Sallis, \& McKenzie, 1991; Sallis, McKenzie, \& Alcaraz, 1993; U.S. DHHS, 2004; Zoeller, 2007). Participation in regular physical activity
(PA) effectively reduces the risk of premature mortality, coronary heart disease, hypertension, colon cancer, and diabetes (Coakley, 2004; Warburton, Nicol, \& Bredin, 2006; Zoeller, 2007). Physical education plays such important role in our society as health costs are at all time high and people are living longer. 
The health benefits of regular physical activity participation and consequences of sedentary lifestyle have officially documented (U.S. Department of Health and Human Services [USDHHS], 2000). These health benefits and consequences for school children are meaningful not only because of current blood pressure control, weight management, and cardiorespiratory function, but because a physically active or inactive lifestyle developed in early life may continue effect into adulthood (USDHHS, 2000). Recent research in the tracking of physical activity has provided increasingly more evidence those levels of physical activity in childhood track, to some degree, into adulthood (Malina, 2001a, 2001b; Telama et al., 2005; Yang et al., 2007). Specifically, research revealed that physical inactivity and obesity remain more stable than physical activity from childhood to adulthood (Anderssen, Wold, \& Torsheim, 2005; Janz, Burns, \& Levy, 2005; Matton et al., 2005; Raitakari, Juonala, \& Viikari, 2005; Yang et al., 2007). That is, compared with physically active lifestyles during childhood, sedentary lifestyles adopted early in life tend to track into adulthood at a higher rate. These findings explained the well known facts that physical activity levels decline from childhood to adulthood and more than half (54.1\%) of adults do not engage in physical activity at the minimum recommended level (Center for Disease Control and Prevention [CDC], 2005).

As a result, the goal of public health is to get physically active children remain physically active through adulthood and, more importantly, to get sedentary children "untracked" and become physically active (Corbin, 2001; Malina, 2001b). In fact, the promotion of lifelong physical activity participation has been recognized as the ultimate goal of school physical education programs (Rink, 2006), and physical activity ranks top in the ten Leading Health Indicators (USDHHS, 2000). Despite all this, participation in all types of physical activity among children continues to decline strikingly as age or grade in school increases (Corbin, Pangrazi, \& Le-Masurier, 2004), and more children are among the sedentary and/or obese category (CDC, 2007; Ogden et al., 2006).

Studies showed that lack of PA among people of all ages is extremely serious and regarded as a major health risk issue (Blair, \& Church, 2004; Johnson, 2008; U.S. DHHS, 2004; Zoeller, 2007). Since the year of 2000, the most significant changes in school PE have been the trend from physical fitness towards promoting and maintaining a healthy lifestyle.
Physical activities in school PE programs have been recognized as ideal paths and environments for developing a healthy lifestyle because of the features of the programs and the high percentage of students enrolled (Graham, Holt/Hale, \& Parker, 2008; Haywood, 1991; Marshall, Sarkin, Sallis, McKenzie, 1998; Pangrazi, 2007). Students' daily participation in PE classes, however, declined from $42 \%$ to $25 \%$ from 1991 to 1995 (U.S. DHHS, 1996). In 2003, only $55.7 \%$ of high school students were enrolled in PE classes, $28.4 \%$ attended PE classes daily, and $39.2 \%$ were physically active during PE classes; additionally, female students and students in higher grades were consistently at greater risks for not reaching the national health objectives for PE (Olafson, 2002; U.S. DHHS, 2004).

With regard to contextual factors, quality physical education programs have been reported to be a strong factor influencing children's attitudes toward physical activity. Children's positive attitudes are likely to be linked with enjoyment, perceived usefulness of the curriculum, and a sense of belongingness (Subramaniam \& Silverman, 2002, 2007). Curriculum with situational interest, such as those require students to analyze and design offensive and defensive strategies, may foster students' interests in physical activity (Chen \& Darst, 2001). A learning environment that promotes personal meaning is considered to be important to the development of positive attitude (Rink, 2006). Children are also likely to become more positive toward physical activity if they are in a learning environment that makes them comfortable and confident (Hagger et al., 2002).

Researchers support the idea that physical activity relieves stress and increases energy levels in one's body. Rothstein (2000) emphasized, "Children need exercise to learn. Scientists say it is plausible that by promoting blood flow to the brain, physical activity increases cognitive power" (p. B11). Warburton, Nicol and Bredin (2006) found that a healthy body and a healthy mind help students learn better and achieve higher.

On the other hand, many helpful and good ideas have been recommended from the fields of physical education and health education. Other than daily physical activities, Researchers and educators suggested that PE should promote physical activities by providing information to students about sports clinics and leagues in the community (Coakley, 2004; Graham, Holt/Hale, \& 
Parker, 2008; Marshall, Sarkin, Sallis, McKenzie, 1998; Pangrazi, 2007). Participating in sports helps keep children connected to their communities.

Specifically, Coakley (2004) recommended that social skills, cooperation attitude and teamwork should be part of PE curriculum, because these skills will benefit a community and bring people together by supporting sport events around the community. Coakley (2004) found that student athletes as a group generally have better grade point averages and a more positive attitude toward school. They continue their education after graduation from high school and have a better achievement rate than nonathletes. Participating in a school team gives students a sense of school pride and improved self-esteem. All of these attributes give students positive educational experiences.

More ideas and suggestions have been made by the researchers such as: using interdisciplinary instructive approach incorporates literacy, math, geography and science into PE classes or lessons, thus making PE programs more valuable for the young generation (Coakley, 2004; Pangrazi, 2007). Teaching PE by "Throwing out balls" is no longer the case in our schools (Graham, Holt/Hale, \& Parker, 2008; Pangrazi, 2007). PE professionals can change their images by developing a science-base curriculum; by applying different technology to provide visual, kinesthetic and auditory stimuli in daily lessons; and by using various teaching strategies to meet the needs of diverse learners (Graham, Holt/Hale, \& Parker, 2008; Pangrazi, 2007).

However, no matter how the researchers, educators and media personnel studied, described, discussed and suggested about the PE and PA issues and solutions in our schools, the bottom line is, the principals are the most influential figures to make decisions on how PE will be operated in their schools. Although there have been many difficulties to identify generic indicators contributing to overall school effectiveness and successful educational reform, research in school effectiveness reform (Fullan, 2001; Graham, Holt/Hale, \& Parker, 2008; Pangrazi, 2007) have consistently identified the role of the principal as a critical contributing factor to school effectiveness and to reform implementation success. The principals at all school levels would be the critical players in the reform efforts for physical education in this large urban city.

\section{Significant of this study}

New York City (NYC) is the most populous and diversely cultured city in the United States with a population of over eight million people. The city is at the center of international finance, politics, entertainment, and culture. The city is composed of Brooklyn, Bronx, Manhattan, Queens, and Staten Island five boroughs. More significantly, the city contains the largest and most complex public school system in the nation, with over 1 million students enrolled throughout 1,200 separate schools. No study, however, have been conducted to involve the principals as research participants in a public school system like NYC where both the school system and the students possess the most diverse characteristics on earth. This is why conduct a research study on perceptions of principals on physical education is crucial to the reform the quality of the public school system in this large urban city. The purposes of this study, therefore, are to gain insights into the principals' perception about physical education and how they evaluate the physical education program in their schools.

\section{Method}

\section{Participants}

For fulfill the objectives of this study, $60-72$ principals from the public school system are needed. This sample represents approximately $5-6 \%$ of the total 1,200 principals in the public school system. The participants will be selected from the five boroughs of the NYC Manhattan, Brooklyn, Bronx, Queens and Staten Island. Voluntarily participate in this study is the essential requirement and each participant will have their signatures on the informed consent forms. Moreover, the researchers should try to recruit one-third of the participants from elementary school $\left(\mathrm{K}-5^{\text {th }}\right)$, middle school $\left(6-8^{\text {th) }}\right.$, and high school $\left(9-12^{\text {th }}\right)$.

\section{Procedures}

The procedures were as follows: (1) obtain an approval for conducting this survey study from the Institutional Review Board (IRB) of the college; (2) contacted to the principals and have the "Inform Consent" signed; and (3) delivered survey packages to 72 principals in the five boroughs' public schools. As the result, 46 principals completed the survey wherein 23 from elementary schools (ES), seven from middle schools (MS) and 16 from high schools (SS). 


\section{Data collection and analyses}

The Principal's perception of Physical Education Questionnaire (PPPEQ, Zeng, 2008) and the SelfEvaluation Tool for School Physical Education Program [National Association for Sport and Physical Education (NASPE), 2000] were employed for this survey. The PPPEQ consists of sixteen statements concerning 'Features of PE Discipline', 'Function of School PE', and 'Challenges School PE Facing' factors. For each statement, the participant can chose 'Agree' (score = 3), 'Disagree' (score $=1$ ), or 'No comment' (score $=2$ ); the highest score could be 48, and the lowest score could be 16 . The SelfEvaluation Tools from the NASPE (2000) comprise nine items concerning qualification of teachers, time allocation, class size, curriculum, facilities, equipment, technology, learning environment, and assessment about school PE program. The participant can evaluate his/her programs as Well-established (score $=3$ ), Established (score = 2), Partially-established (score $=1$ ), or Not-established (no score). The highest score could be 27 , and the lowest score could be 0 . Techniques for data analyzing included Pearson product-moment correlation and an individual group $t$ test.

\section{Results and Discussions}

The objectives of this survey were to obtain the insights into principals' perception about physical education and how they self-evaluate the physical education program in their schools. The results showed the following features: first, the mean score over the sixteen statements on Principal's perception of Physical Education Questionnaire (PPPEQ, Zeng, 2008) survey for the principals was $\mathrm{M}_{\text {Total }}$ $=2.580$; this indicated that the PE perception statements were accepted by the principals. The top five statements that strongly structured the principals' PE perception were: Item 2 - "We can activate and foster the physical activity skills children need through our school physical education programs", mean score $(\mathrm{M})=2.978$ (full score $=3.000$ ). Item 11 - "Once physical education and daily physical activities are valued and supported, children will gradually form their active and healthy lifestyle", $\mathrm{M}=2.935$. Item 1, 6, and 16 - "Physical education plays a vital role in our school curricula." "Obesity is a major health issue in our young generation that can be prevented by improving school physical education programs" and "Physical education is an ideal course for kids to obtain knowledge, motivation, skills, and confidence to develop and maintain an active and healthy lifestyle." All three items' $\mathrm{M}=2.913$. The frequency of participants responded on the PPPEQ can be found in Table one. Table 1. Descriptive Statistics of the Participants Who Scored on the Questionnaire of
Principal's Perception about Physical Education $(N=46)$.

M SD SUM

1. Physical education plays a vital role in our school curricula.

2. We can activate and foster the physical activity skills children need through our school physical education programs.

3. Physical education is an academic discipline and just as important as English, Math and Sciences to our students.

4. Physical education is the only discipline that can mold children into healthy whole persons by providing opportunities to develop physically, socially and emotionally.

5. Without physical education in our school curricula, our students will not be fully developed.

6. Obesity is a major health issue in our young generation that can be prevented by improving school physical education programs.

7. Our children are much harder to motivate for participating in regular physical activities than ever before.

8. Parental supports for daily physical activities in our school are rarer than ever before.

$\begin{array}{lll}1.652 & .822 \quad 76.00\end{array}$


9. Financial budget cuts have great impact on our physical education facility and equipment.

10. With certified physical educators teaching physical education starting at elementary level will plant good seeds for positive attitude towards physical education.

11. Once physical education and daily physical activities are valued and supported, children will gradually form their active and healthy lifestyle.

12. Having daily physical education class is the key to prevent kids from becoming overweight.

13. To build up valuable physical education programs, having certified physical education specialists is the key.

14. Safe environment, necessary facilities and equipment is the key for kids to regularly participate in physical activities.

15. After-school physical activity and sport programs are crucial for kids to become physically educated person.

16. Physical education is an ideal course for kids to obtain knowledge, motivation, skills, and confidence to develop and maintain an active and healthy lifestyle.
2.456

.862

113.00

$2.739 \quad .647$

126.00

2.935

108.00

Note: $\mathrm{M}=$ Mean, $\quad \mathrm{SD}=$ Standard Deviation, $\quad \mathrm{SUM}=$ Sum of total mean.

Second, with regard to the self-evaluation for school PE Program, the top three higher score among the nine items were item 7 - "the curriculum", $M=2.261$ (full score =3.000); item 1 -"qualification of teachers", $\mathrm{M}=$ 2.152; and item 3 - "the class-size", $M=2.043$; the bottom two lower score among the nine items were item 5 - "technology", M = 1.391; and item 8 - "student assessment", $\mathrm{M}=1.587$. When comparing these evaluation results with the full score of $\mathrm{M}=3.000$, the participants expressed that they were far from satisfaction on their school PE programs. Descriptive statistics of the principals who did a self-evaluation on their schools' PE programs can be found in table 2 .

Table 2. Descriptive Statistics of the Participants who did a Self-Evaluation on Their Schools' Physical Education Programs $(\mathrm{N}=46)$.

\begin{tabular}{lllll}
\hline Items for Evaluation & $\mathrm{N}$ & $\mathrm{M}$ & $\mathrm{SD}$ & SUM \\
\hline 1. Qualification of teachers & 46 & 2.152 & .893 & 98.992 \\
2. Time allocation & 46 & 1.826 & .877 & 83.996 \\
3. Class size & 46 & 2.043 & 1.173 & 93.978 \\
4. Equipment and materials & 46 & 1.956 & .758 & 89.976 \\
5. Technology & 46 & 1.391 & .881 & 63.986 \\
6. Facilities & 46 & 1.978 & .774 & 90.988 \\
7. Curriculum & 46 & 2.261 & .801 & 104.006 \\
8. Student assessment & 46 & 1.587 & .805 & 73.002 \\
9. Program evaluation & 46 & 1.956 & .842 & 89.976
\end{tabular}

Note. A. The participants can make decision on four options in each item as (a) Not Established, score = 0; (b) Partially Established, score $=1$; (c) Established, score $=2$; and (d) Well Established, score $=3$; therefore, the highest score for each participant is 27, and the lowest score is 0 . B. The sum full score for each item for the 46 participants is 138. 
Table 3. Correlation Coefficients between of the Score on Perception of Physical Education and SelfEvaluation to PE Program by the Principals $(\mathrm{N}=46)$.

\begin{tabular}{llcccccccc}
\hline Variable & QOT & TA & CS & EQMA & TECH & FACI & CURI & STAS & PREV \\
\hline STAT 1 & -.238 & .022 & .223 & -.262 & .254 & -.169 & .082 & .027 & -.162 \\
STAT 2 & .026 & .142 & -.123 & -.009 & .067 & -.004 & -.139 & .110 & -.008 \\
STAT 3 & $.485^{* *}$ & -.052 & -.055 & .085 & .068 & .107 & .107 & .239 & .197 \\
STAT 4 & .010 & -.016 & .073 & .020 & .129 & .026 & -.177 & -.085 & .048 \\
STAT 5 & .035 & $.322^{*}$ & .016 & -.237 & -.253 & .179 & -.065 & -.175 & -.060 \\
STAT 6 & -.084 & -.166 & -.084 & -.012 & .096 & .133 & -.064 & .023 & -.011 \\
STAT 7 & $-.306^{*}$ & .117 & .083 & .034 & -.233 & -.126 & -.161 & -.140 & -.028 \\
STAT 8 & .164 & .099 & $.364 *$ & -.203 & -.023 & -.047 & -.264 & .013 & -.151 \\
STAT 9 & -.033 & .284 & .068 & .065 & .052 & -.051 & .049 & -.267 & -.095 \\
STAT 10 & -.160 & -.043 & .249 & -.069 & .105 & -.189 & -.080 & $.300^{*}$ & .182 \\
STAT 11 & -.041 & .115 & -.166 & -.012 & .013 & -.094 & -.018 & .149 & -.011 \\
STAT 12 & -.012 & -.035 & .028 & .057 & -.008 & -.218 & .058 & -.012 & .111 \\
STAT 13 & -.191 & .067 & -.041 & -.159 & -.112 & -.012 & .271 & $-.310^{*}$ & -.023 \\
STAT 14 & $.341^{*}$ & .088 & -.026 & .267 & -.160 & .047 & .045 & .167 & .138 \\
STAT 15 & -.143 & -.229 & .053 & -.021 & -.149 & -.188 & $.348^{*}$ & $-.358^{*}$ & -.073 \\
STAT 16 & -.098 & .093 & -.205 & .151 & .254 & $.398^{* *}$ & -.231 & .185 & .210 \\
\hline
\end{tabular}

Note. * Correlation coefficient is significant at the 0.05 Level (2-tailed). ** Correlation coefficient is significant at the 0.01 Level (2-tailed). $\mathrm{QOT}=$ Qualification of teachers; $\mathrm{TA}=$ Time allocation; $\mathrm{CS}=$ Class size; $\mathrm{EQMA}=$ Equipment and materials; $\mathrm{TECH}=$ Technology; FACI = Facilities; CURI = Curriculum; STAS = Student assess; and PREV = Program evaluation. ***10 rs showed significant in which 8 rs significant at 0.05 Level, and 2 rs significant at 0.01 Level.

Third, the correlation analyses found that there were 10 correlations (rs) showed significant in which 8 rs were significant at 0.05 Level, and 2 rs were significant at 0.01 Level. For examples, PE perception 3, "Physical education is an academic discipline and just as important as English, Math and Sciences to our students." VS "qualification of teachers" - rs $=.485, \mathrm{p}=.01$ reflected that the principals are strongly view $\mathrm{PE}$ as an academic discipline and believe that a quality PE program has definitely connection with teachers' qualification (e.g., a certification in the field). PE perception 5, "Without physical education in our school curricula, our students will not be fully developed." VS "time allocation" rs $=.322, p=.05$ reflected that the principals clearly recognized that in order for their students receiving the 'whole person education', PE must be included in school curricula and reasonable mandated PE hours is necessary. The correlation coefficients between of the score on perception of $\mathrm{PE}$ and Self-Evaluation to $\mathrm{PE}$ program by the principals were presented in Table 3 .

Last, the comparison analysis found that on the principals' self-evaluation results, some significant differences do exist between the ES principals and the SS principals. Specifically, four out of nine items released significant differences exist; e.g., in "class-size", the ES principals indicated that was established, the SS principals indicated that was not; in "program evaluation" the SS principals indicated that was established, the ES principals indicated that was not. The independent group t-Test for determining whether differences exist or not on Self-Evaluation to their school PE Program by the Principals was presented in Table 4. 
Table 4. Independent Group t-Test for Determining whether Differences Exist or not on Self-Evaluation to Their School Physical Education Program by the Participants $\left(N=46\right.$, where Group $_{1}=23$ were from elementary schools, and Group ${ }_{2}=23$ were from secondary schools).

\begin{tabular}{|c|c|c|c|c|c|c|}
\hline Items & Group & M & $\mathrm{t}$ & df & $\mathrm{p}$ & SE \\
\hline \multirow[t]{2}{*}{ Class Size } & Group $_{1}$ & 2.565 & & & & .164 \\
\hline & Group $_{2}$ & 1.522 & 3.340 & 44 & .002 & .265 \\
\hline \multirow[t]{2}{*}{ Technology } & Group $_{1}$ & 1.087 & & & & .153 \\
\hline & Group $_{2}$ & 1.696 & -2.471 & 44 & .017 & .193 \\
\hline \multirow[t]{2}{*}{ Student assessment } & Group $_{1}$ & 1.696 & & & & .132 \\
\hline & Group $_{2}$ & 1.869 & -2.519 & 44 & .015 & .181 \\
\hline \multirow[t]{2}{*}{ Program evaluation } & Group $_{1}$ & 1.304 & & & & .132 \\
\hline & Group $_{2}$ & 2.212 & -2.198 & 44 & .034 & .198 \\
\hline
\end{tabular}

Note. (a) Only the above four items had significant differences, $\mathrm{P}<.05$; the other five items - Qualification of teachers; Time allocation; Equipment and materials; Technology; and Curriculum showed no significant differences, P > .05. And (b) $\mathrm{M}=$ Mean, $\mathrm{SE}=$ standard error.

\section{Conclusion}

In conclusion, the physical education perception (PE) developed through review of literature was accepted by the principals, the top five statements that strongly structured the principals' PE perception were Item 2 -"We can activate and foster the physical activity skills children need through our school physical education programs.", 11 -- "Once physical education and daily physical activities are valued and supported, children will gradually form their active and healthy lifestyle.", 1 -- "Physical education plays a vital role in our school curricula.", 6 -- "Obesity is a major health issue in our young generation that can be prevented by improving school physical education programs.", and 16 - "Physical education is an idea course for kids to obtain knowledge, motivation, skills, and confidence to develop and maintain an active and healthy lifestyle.".
Regarding self-evaluation for their school PE Program, the principals indicated that their school PE programs were not well-established; some particular areas were far from satisfaction. The relationship between the principals' PE perception and self-evaluations on their schools' PE program exists with some correlations stronger than others. Additionally, some significant differences are found on the self-evaluation to school PE programs between the elementary school principals and the secondary school principals. The findings are meaningful for the school curriculum reform and promoting quality PE and PA programs in both elementary and secondary schools. On the other hand, limitations on the quantities of the participants is visible, more studies on this topic are needed. 


\section{References}

Anderssen, N., Wold, B., \& Torsheim, T. (2005). Tracking of physical activity in adolescence. Research Quarterly for Exercise \& Sport, 76, 119-129.

Blair, S. N., \& Church, T. S. (2004). The Fitness, Obesity, and Health Equation: Is Physical Activity the Common Denominator? The Journal of the American Medical Association, Circulation, 292, 1232-1234.

Centers for Disease Control. (CDC, 2004). School Health Index: A Self-Assessment and Planning Guide. Middle school/high school version. Atlanta, Georgia: U.S. Department of Health and Human Services, CDC, 2004.

Center for Disease Control and Prevention. (CDC, 2005, December 2). Adult participation in recommended levels of physical activity - United States, 2001-2003. Morbidity and Mortality Weekly, 54, 1208-1212.

Center for Disease Control and Prevention. (CDC, 2007). Overweight Prevalence. Retrieved November 30, 2007, fromhttp://www.cdc.gov/nccdphp/dnpa/obesity/childhood/ prevalence.htm

Chen, A., \& Darst, P. W. (2001). Situational interest in physical education: A function of learning task design. Research Quarterly for Exercise and Sport, 72, 285-306.

Coakley, J. (2004). Sports in society: Issues and controversies (8th ed.). McGraw Hill: New York.

Corbin, C. B. (2001). The "untracking" of sedentary living: A call for action. Pediatric Exercise Science, 13, 347-356.

Fullan, M. (2006). Leading in a Culture of Change. www.michaelfullan.ca.

Graham, G., Holt/Hale, S. A. and Parker, M. (2008). Children moving: A reflective approach to teaching physical education ( $8^{\text {th }}$ Ed.). Mountain View, CA: Mayfield.
Haywood, K. M. (1991). The role of physical education in the development of active lifestyles. Research Quarterly for Exercise and Sport, 62, 151-156.

Janz, K. F., Burns, T. L., \& Levy, S. M. (2005). Tracking of activity and sedentary behaviors in childhood: The Iowa Bone Development Study. American Journal of Preventive Medicine, 29, 171-178.

Johnson, F. (2008). Some teachers integrate outdoor activities into fitness curriculum. Washington State's Olympian (1/14).

Malina, R. M. (2001a). Physical activity and fitness: Pathways from childhood to adulthood. American Journal of Human Biology, 13, 162-172.

Malina, R. M. (2001b). Tracking of physical activity across the lifespan. President's Council on Physical Fitness and Sports Research Digest, 3(14), 1-8.

Marshall, S. J.; Sarkin, J., Sallis, J. F., McKenzie, T. L. (1998). Tracking of health-related fitness components in youth ages 9 to 12. Medicine \& Science in Sports \& Exercise. 30, 910-916.

Matton, L., Thomis, M., Wijndaele, K., Duvigneaud, N., Beunen, G., Claessens, A. L., et al. (2005). Tracking of physical fitness and physical activity from youth to adulthood in females. Medicine \& Science in Sports \& Exercise, 38, 1114-1120.

Ogden, C. L., Carroll, M. D., Curtio, L. R., McDowell, M. A., Tabak, C. J., Flegal, K. M., et al. (2006). Prevalence of overweight and obesity in the United States, 19992004. Journal of American Medical Association, 295, 1549-1555.

Olafson, L. (2002). "I hate phys. ed.": Adolescent girls talk about physical education. The Physical Educator, spring, 67-74.

Pangrazi, R. P. (2007). Dynamic physical education for elementary school children $\left(15^{\text {th }}\right.$ ed.). San Francisco, CA: Benjamin Cummings. 
Raitakari, O. T., Juonala, M., \& Viikari, J. S. A. (2005). Obesity in childhood and vascular changes in adulthood: Insights into the Cardiovascular Risk in Young Finns Study. International Journal of Obesity, 29, S101-S104.

Rink, J. (2006). Teaching physical education for learning $\left(5^{\text {th }}\right.$ ed.). New York: McGraw-Hill.

Rothstein, R. (2000). Are the Three R's Crowding Out P.E.? The New York Times, 11/29/2000.

Sallis, J., \& McKenzie, T. L. (1991). Physical education's role in public health. Research Quarterly for Exercise and Sport, 62, 124-137.

Sallis, J. F., McKenzie, T. L., \& Alcaraz, J. E. (1993). Habitual physical activity and health-related physical fitness in fourth-grade children. American Journal of Diseases of Children, 147, 890-896.

Subramaniam, P. R., \& Silverman, S. (2002). Using complimentary data: An investigation of student attitude in physical education. Journal of Sport Pedagogy, 8:74-91, 2002.

Subramaniam, P. R., \& Silverman, S. (2007). Middle school students' attitudes toward physical education. Teaching and Teacher Education, 23, 602-611.

Telama, R., Yang, X., Viikari, J., Välimäki, I., Wanne, O., \& Raitakari, O. (2005). Physical activity from childhood to adulthood: A 21-year tracking study. American Journal of Preventive medicine, 28, 267-273.

U.S. Department of Health and Human Services (U.S DHHS, 1996). Physical activity and health: A report of the Surgeon General. Atlanta, GA: U.S. Centers for Disease Control and Prevention, National Center for Chronic Disease Prevention and Health Promotion.

U.S. Department of Health and Human Services (U.S. DHHS, 2000). Physical activity and health: A report of the Surgeon General. Atlanta, GA: U.S. Centers for Disease Control and Prevention, National Center for Chronic Disease Prevention and Health Promotion.
Warburton, D.E., Nicol, C., \& Bredin, S.S. (2006). Health benefits of physical activity: the evidence. Canadian Medical Association Journal (CMAJ), 174, 801-9.

Yang, X., Telama, R., Leskinen, E., Mansikkaniemi, K., Viikari, J., \& Raitakari, O. T. (2007). Testing a model of physical activity and obesity tracking from youth to adulthood: The Cardiovascular Risk in Young Finns Study. International Journal of Obesity, $31,521-527$

Zeng, Z. H., Liu, W. H., \& Hipscher M. (2009). Urban School Physical Education Directors Perceptions of Physical Education. Paper presented in 2009 AAHPERD National Convention and published in Research Quarterly for Exercise and Sport, Suppl, 80.

Zoeller, R. F. (2007). Physical Activity and Obesity: Their Interaction and Implications for Disease Risk and the Role of Physical Activity in Healthy Weight Management. The Journal of the American Medical Association, 1, 437-446.

\section{Correspondence}

Howard Z. Zeng, D. P. E. Department of Physical Education and Exercise Science The City University of New York, Brooklyn College 2900 Bedford Avenue, Brooklyn, NY 11210, USA Tel: 718-951-4427; Fax: 718-951-4541

Email: hzeng@brooklyn.cuny.edu 


\section{Appendix A. Questionnaire of Principal's Perception about Physical Education \\ For the survey project in the Public Schools of the NYC}

\section{Perception of Physical Education -. Special Scale for Principal}

1. Physical education plays a vital role in our school curricula.
Agree
No comment
Disagree

2. We can activate and foster the physical activity skills children need through our school physical education programs Agree No comment Disagree

3. Physical education is an academic discipline and just as important as English, Math and Science to our students.
Agree
No comment
Disagree

4. Physical education is the only discipline that can mold children into healthy whole persons by providing opportunities to develop physically, socially and emotionally.
Agree
No comment
Disagree

5. Without physical education in our school curricula, our students will not be fully developed.
Agree
No comment
Disagree

6. Obesity is a major health issue in our young generation that can be prevented by improving school physical education programs.
Agree
No comment
Disagree

7. Our children are much harder to motivate for participating in regular physical activities than ever before. Agree
No comment
Disagree

8. Parental supports for daily physical activities in our school are rare than ever before.
Agree
No comment
Disagree

9. Financial budget cuts have great impact on our physical education facility and equipment. Agree
No comment
Disagree

10. With certified physical educators teaching physical education starting at elementary level will plant good seeds for positive attitude towards physical education.
Agree
No comment
Disagree

11. Once physical education and daily physical activities are valued and supported, children will gradually form their active and healthy lifestyle.
Agree
No comment
Disagree

12. Having daily physical education class is the key to prevent kids from becoming overweight.
Agree
No comment
Disagree

13. To build up valuable physical education programs, having certified physical education specialists is the key.
Agree
No comment
Disagree

14. Safe environment, necessary facilities and equipment is the key for kids to regularly participate in physical activities.
Agree
No comment
Disagree

15. After-school physical activity and sport programs are crucial for kids to become physically educated person.
Agree
No comment
Disagree

16. Physical education is an idea course for kids to obtain knowledge, motivation, skills, and confidence to develop and maintain an active and healthy lifestyle.
Agree
No comment
Disagree 
17. * In your opinion, what are some challenges and opportunities for the physical education program in your school? challenges

opportunities

*Note that this question did not included in the present survey but it is recommended for the use of further research.

\section{Self-Evaluate Scale for School Physical Education Program}

\section{Dear Principal,}

The following is a self-evaluation tool for school physical education program please makes a quick evaluation for your school program by circling one description that you believe is most appropriate:

Direction: According to the Opportunity to Learn: Standards for Physical Education (NASPE, 2000), please make a selfevaluation for your school's PE program in the following nine subcategories.

1. Qualification of teachers.
a. Not Established
b. Partially Established
c. Established
d. Well Established

2. Time allocation
a. Not Established
b. Partially Established
c. Established
d. Well Established

3. Class size.
a. Not Established
b. Partially Established
c. Established
d. Well Established

4. Equipment and materials.
a. Not Established
b. Partially Established
c. Established
d. Well Established

5. Technology
a. Not Established
b. Partially Established
c. Established
d. Well Established

6. Facilities
a. Not Established
b. Partially Established
c. Established
d. Well Established

7. Curriculum
a. Not Established
b. Partially Established
c. Established
d. Well Established

8. Student assessment
a. Not Established
b. Partially Established
c. Established
d. Well Established

9. Program evaluation
a. Not Established
b. Partially Established
c. Established
d. Well Established 